\title{
New records of Leptophis ahaetulla ahaetulla (Serpentes, Colubridae) for Venezuela, Colombia and the placement of $L$. a. copei into the synonymy of $L$. a. ahaetulla
}

\author{
Nelson Rufino de Albuquerque ${ }^{1,2}$ \\ ${ }^{1}$ Departamento de Ciências do Ambiente, Universidade Federal de Mato Grosso do Sul-UFMS \\ Av. Rio Branco 1270, Campus do Pantanal, CEP 79304-020, Corumbá, MS, Brazil \\ ${ }^{2}$ Corresponding author: Nelson Rufino de Albuquerque, e-mail: nelson.rufino@ufms.br
}

ALBUQUERQUE, N.R. New records of Leptophis ahaetulla ahaetulla (Serpentes, Colubridae) for Venezuela, Colombia and the placement of $\boldsymbol{L}$. a. copei into the synonymy of $\boldsymbol{L}$. a. ahaetulla. Biota Neotrop. 9(4): http:// www.biotaneotropica.org.br/v9n4/en/abstract?short-communication+bn03209042009.

Abstract: The taxonomic validity of Leptophis ahaetulla copei is assessed. This subspecies is distinct from the nominal subspecies on the basis of differences in the number of ventral scales, maxillary teeth and dorsal coloration. However, comparison of its type specimens with specimens of $L$. a. ahaetulla revealed that $L$. $a$. cope $i$ is a junior synonym of the latter. In addition, the distribution of L. a. ahaetulla is expanded from Brazil to southwestern Venezuela and southern Colombia.

Keywords: Leptophis ahaetulla, taxonomy, distribution, South America.

ALBUQUERQUE, N.R. Novos registros de Leptophis ahaetulla ahaetulla (Serpentes, Colubridae) para Venezuela, Colômbia e a colocação de $L$. a. copei na sinonímia de L. a. ahaetulla. Biota Neotrop. 9(4): http:// www.biotaneotropica.org.br/v9n4/pt/abstract?short-communication+bn03209042009.

Resumo: A validade taxonômica de Leptophis ahaetulla copei é avaliada. Esta subespécie é distinta da subespécie nominal com base em diferenças no número de escamas ventrais, dentes maxilares e coloração dorsal. Porém, uma comparação dos seus espécimes-tipo com espécimes de $L$. a. ahaetulla revelou que L. a. copei é um sinônimo júnior desta última. Em adição, a distribuição de L. a. ahaetulla é expandida do Brasil para o sudoeste da Venezuela e sul da Colômbia.

Palavras-chave: Leptophis ahaetulla, taxonomia, distribuição, América do Sul. 


\section{Introduction}

As defined by Oliver (1948) and Mertens (1973) the Neotropical tree snake Leptophis ahaetulla (Linnaeus, 1758) contains 12 subspecies: L. a. ahaetulla, L. a. bocourti, L. a. bolivianus, L. a. coeruleodorsus, L. a. copei, L. a. liocercus, L. a. marginatus, L. a. nigromarginatus, L. a. occidentalis, L. a. ortoni, L. a. praestans and L. a. urosticus.

Prior to its recognition as a distinct subspecies of L. ahaetulla, Oliver (1942) described Leptophis copei from three specimens collected at the Venezuela-Brazil boundary on Salto do Huá, one specimen from San Antonio, upper Orinoco River, Venezuela, and two specimens from the Colombia-Brazil boundary on Vaupés, upper Carurú River. Oliver (1942) did not propose a formal diagnosis of a new taxon; rather, he furnished morphometric and meristic data such as the number of ventral and subcaudal scales and snout-vent length, in addition to the variation observed on the black ocular stripe and dorsal coloration of the type specimens. Subsequently, Oliver (1948: 231) redescribed the pattern of coloration of L. a. copei in detail, pointing out that the anterior body coloration of this subspecies differs from that on the posterior region of the body. According to Oliver (1948), the dorsal coloration pattern of L. a. copei consists of two dark lateral stripes separated from each other by a light gray to light brown vertebral stripe, which is always obliterated on the midbody, with the exception of irregular spots on concealed portions of scales.

Oliver (1948: 201) used the presence of two dark blue dorsolateral stripes separated by a light vertebral stripe, which always continues onto the tail, to distinguish L. a. ahaetulla from the other subspecies of L. ahaetulla. Oliver (1948: 232) stated also that L. a. ahaetulla differs from $L$. a. copei in having a lower average number of maxillary teeth (25.3 vs. 27) and a lower number of ventral scales (156-178 vs. 173-179). Availability of new specimens in several museum collections revealed, however, that there is more geographic variation in L. a. ahaetulla than previously assumed by Oliver (1948).

\section{Material and Methods}

I compared specimens from the type series of L. copei with specimens from the Roraima State, Amapá, Amazonas, Pará, western Maranhão, Venezuela, and data from Cunha \& Nascimento (1993) (Appendix). In addition, I counted the number of maxillary, palatine, pterygoid, and dentary teeth of MHNLS 14011, MPEG 17375 and UMMZ 149833. The map was made with the program ArcView GIS with some localities obtained from the on line version of the Global Gazetteer Version 2.1 by Falling Grain Genomics (http://www.fallingrain.com/world/). Skulls were removed by peeling back the skin from the mouth such that head integument remained intact and with the rest of the specimen. A pair of forceps and a small surgical scissors was used to cut the skin. The extracted skulls were prepared as dry skeletons. Ventral scales were counted according to Dowling (1951).

Table 1. Number of maxillary, palatine, pterygoid, and dentary teeth counted in three skulls of L. a. ahaetulla.

Tabela 1. Número de dentes maxilares, palatinos, pterigóideos, e dentários contados em três crânios de L. a. ahaetulla.

\begin{tabular}{lcccc}
\hline \multicolumn{1}{c}{ Specimens } & Maxillary & Palatine & Pterygoid & Dentary \\
\hline MPEG 17375 $($ ふ $)$ & $27 / 26$ & $16 / 18$ & $30 / 30$ & $28 / 28$ \\
MHNLS 14011 (q) & $27 / 27$ & $16 / 16$ & $28 / 28$ & $* / *$ \\
UMMZ 149833 (す) & $27 / 26$ & $15 / 16$ & $27 / 25$ & $26+/ 28+$ \\
\hline
\end{tabular}

\section{Results and Discussion}

The analysis revealed that the variation in number of ventral and subcaudal scales and number of maxillary teeth, which were employed by Oliver (1948) for the diagnosis of L. a. copei, falls within the variation of L. a. ahaetulla (Tables 1 and 2). I examined specimens from

Table 2. Variation in number of ventral scales for all specimens of L. a. ahaetulla examined in this study. *Paratypes of L. copei; **Holotype of L. copei.

Tabela 2. Variação no número de escamas ventrais para todos os espécimes de L. a. ahaetulla examinados neste estudo. *Parátipos de L. copei; **Holótipo de L. copei.

\begin{tabular}{|c|c|c|}
\hline Specimens & Locality & Ventrals \\
\hline IBSP $13778(\delta)$ & Oiapoque, Amapá & 172 \\
\hline MHNLS 14011 (우) & Río Siapa, Amazonas & 172 \\
\hline MPEG $16567(q)$ & Barcarena, Pará & 172 \\
\hline AMNH $4464(\lesssim)^{*}$ & upper Carurú River, Vaupés & 173 \\
\hline INPA $9783($ () & Parque Nacional do Jaú, Amazonas & 173 \\
\hline MPEG $17394(q)$ & Presidente Figueiredo, Amazonas & 173 \\
\hline MPEG $17379(\precsim)$ & Presidente Figueiredo, Amazonas & 174 \\
\hline MPEG $1554(q)$ & Castanhal, Pará & 174 \\
\hline MZUSP $5470(\precsim)$ & Santa Isabel do Rio Negro, Amazonas & 175 \\
\hline USNM $83570(q)^{*}$ & Salto do Huá, Amazonas & 176 \\
\hline USNM $83617(\precsim) *$ & upper Orinoco River, Amazonas & 176 \\
\hline MPEG $477(q)$ & Taiano village, Roraima & 176 \\
\hline MPEG 19774 (q) & Oriximiná, Pará & 176 \\
\hline AMNH $4463(ð)^{*}$ & upper Carurú River, Vaupés & 177 \\
\hline AMNH $38097(\precsim)^{*}$ & Santa Isabel, Amazonas & 177 \\
\hline MZUSP 9986 (q) & Confiança village, Roraima & 177 \\
\hline HUFMA $288(+)$ & Urbano Santos, Maranhão & 179 \\
\hline USNM $83564(ठ ̋)^{* *}$ & Salto do Huá, Amazonas & 179 \\
\hline MPEG 17021 (q) & Rio Fresco, Pará & 192 \\
\hline
\end{tabular}

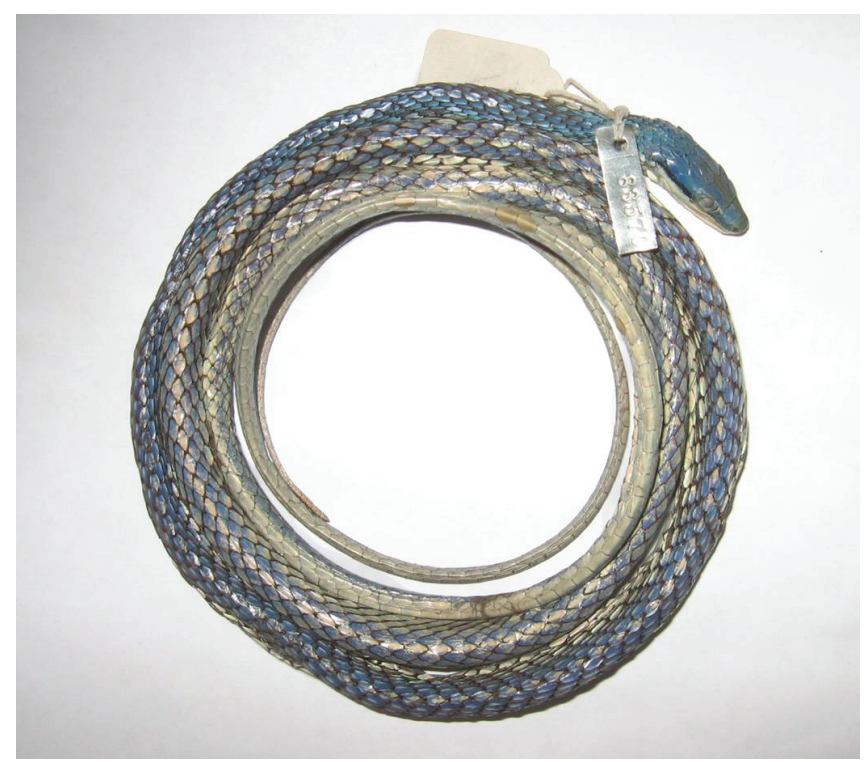

Figure 1. Paratype of Leptophis copei (USNM 83570). Note the two blue dorsolateral stripes separated from each other by a vertebral stripe along the entire length of the body.

Figura 1. Parátipo de Leptophis copei (USNM 83570). Note as duas faixas dorsolaterais azuis separadas uma da outra por uma faixa vertebral ao longo do comprimento total do corpo. 


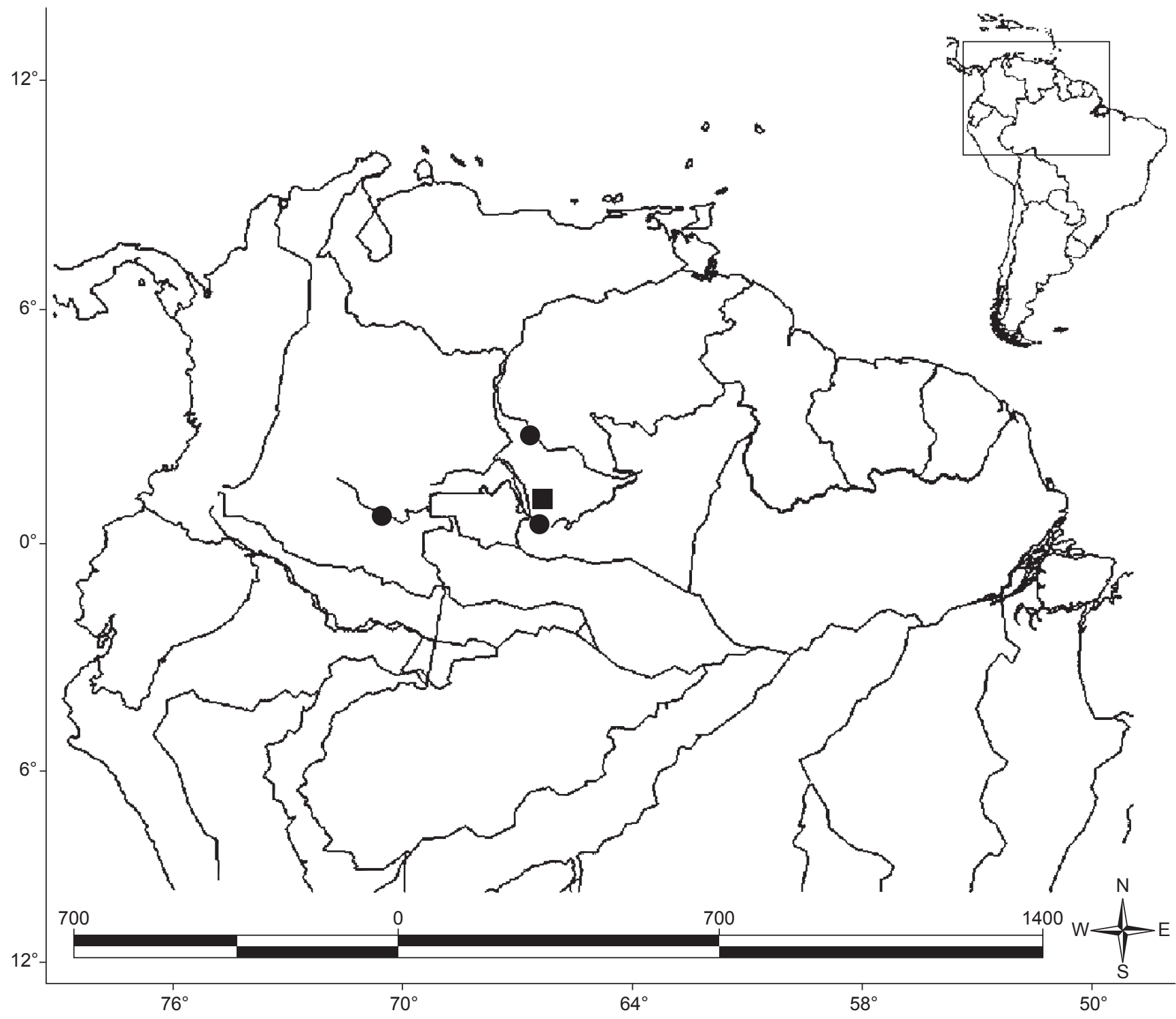

Figure 2. New records of Leptophis ahaetulla ahaetulla for Venezuela and Colombia based on specimens formerly described as Leptophis copei (circles) and the specimen MHNLS 14011 (square).

Figura 2. Novos registros de Leptophis ahaetulla ahaetulla para Venezuela e Colômbia baseado em espécimes previamente descritos como Leptophis copei (círculos) e no espécime MHNLS 14011 (quadrado).

eastern Pará (L. a. ahaetulla), (see Cunha \& Nascimento 1993) where the dorsal stripes are not continuous for the entire length of the body, becoming diffuse at mid-body (see also Cunha \& Nascimento 1993, for description of dorsal coloration). On the other hand, I examined the type series of $L$. copei and noted that in some of the paratypes the dorsal stripes are continuous for the entire length of the body (Figure 1). The dorsolateral stripes are not visible in the midbody of holotype of $L$. copei because the color faded over time, so that the original color pattern is absent.

Thus there in no reason to maintain L. a. ahaetulla and L. a. copei as distinct taxa; L. a. copei should be placed as a junior synonymy of
L. a. ahaetulla and the distribution of the latter expanded to southwestern Venezuela and southern Colombia (Figure 2).

\section{Acknowledgements}

I would like to thank Darrel R. Frost and David Kizirian (AMNH), Roy W. McDiarmid and Steve Gotte (USNM) for access to specimens under their care. I also thank Ana Prudente (MPEG), Francisco L. Franco (IBSP), Gilda V. Andrade (UFMA), Gilson Rivas (MHNLS), Greg Schneider (UMMZ), Hussam Zaher (MZUSP) and Richard Vogt (INPA), who kindly loaned specimens and Robert Pascocello 
Albuquerque, N.R.

for english revision. Coordenação de Aperfeiçoamento de Pessoal de Nível Superior (CAPES) provided me a partial doctoral fellowship to support my studies while at the American Museum of Natural History.

\section{References}

CUNHA, O.R. \& NASCIMENTO, F.P. 1993. Ofídios da Amazônia X: as cobras da região Leste do Pará. Bol. Mus. Para. Emilio Goeldi. 31(1):1-191.

DOWLING, H.G. 1951. A proposed standard system of counting ventral scales in snakes. Brit. J. Herpetol. 1:97-99.

FALLING GRAIN GENOMICS. 1996. Global Gazetteer. Version 2.1. Palo Alto, CA. http://www.fallingrain.com/world/ (accessed 16 August 2009).
MERTENS, R. 1973. Bemerkenswerte Schlangnatters der neotropischen Gattung Leptophis. Stud. Neotrop. Fauna Environ. 8:141-154.

OLIVER, J.A. 1942. A check list of the snakes of the genus Leptophis, with descriptions of new forms. Occas. Papers Mus. Zool. Univ. Mich. 462:1-19.

OLIVER, J.A. 1948. The relationships and zoogeography of the genus Thalerophis Oliver. Bull. Am. Mus. Nat. Hist. 92(4):157-280.

Recebido em 18/08/09

Versão reformulada recebida em: 26/11/09

Publicado em 01/12/09 